\title{
Support and reinforcement damage initiation and design adjustments in a deep mine environment Case study: Cuiabá Mine, Minas Gerais, Brazil
}

\author{
L.C.B. Costa, R.C. Padula, L.M.V. Pimenta, R.S. Pereira, and D.T. Peterle \\ Anglogold Ashanti, Brazil
}

\begin{abstract}
As the deepening of an underground mine occurs, dynamic events (rockbursts) or high deformation ground conditions can occur. The Cuiabá underground gold mine (AngloGold Ashanti, Minas Gerais, Brazil) which is around $1300 \mathrm{~m}$ deep, started to experience some of these issues. High deformation associated with bulking and buckling was experienced in the main decline resulting in many rehabilitation stages. Aiming to better understand and reduce the impact of this behaviour, a damage mapping of the support and reinforcement were carried out in the Serrotinho decline.
\end{abstract}

Field measurements of deformation were also undertaken. It was then possible to correlate the numerical modeling outputs with the observed damage and suggest design changes. Based on the observed mechanisms, as well as the reinforcement and support damage experienced in the decline, laboratory tests were necessary to adjust the rock bolt face plate capacity and redefine the most adequate rock bolt and surface support combination to guarantee the functionality of the whole support system.

\section{INTRODUCTION}

High deformable ground over time without any major stress field changes, often referred to as squeezing ground conditions, represents a significant obstacle in the construction and maintenance of underground excavations in rock ,Potvin and Hadjigeorgiou (2008). Mines with this condition have significant challenges to keep the excavations open and operational and often incur considerable expenses in rock reinforcement and support as well as time-consuming rehabilitation, MercierLangevin and Hadjigeorgiou (2011).

According to Mercier-Langevin and Hadjigeorgiou (2011), the majority of the currently documented case studies in high deformable ground are from the tunneling industry and not from mining, for example Steiner (1996), Aydan et al (1996) and Barla et al (2007). This process is normally associated with soft and/or weak rock types, but large deformations are also observed in hard rocks if both structure and high stress are present.

It is common not to recognize or to underestimate the conditions leading to squeezing ground during the feasibility stage of a project, which then causes significant difficulties in mining the deposit, higher costs and lost resources Varden et al.(2015). Field observations of the mechanism, associated with the geological-geotechnical characterization, monitoring, numerical modeling as well as support damage analysis can assist in understanding the problem as well as to define actions to solve it. 


\section{AREA OF STUDY}

Cuiabá mine is located near the city of Sabará, in the northwest portion of the Iron Quadrilateral Central region of the inland state of Minas Gerais, Brazil. The underground gold mine (owned and operated by AngloGold Ashanti), is currently operating up to $1300 \mathrm{~m}$ below surface, with sublevel stoping as the main mining method. It is currently one of the deepest operating mines in Brazil. The study presented in this paper is related to the Serrotinho decline, one of the main declines of the Cuiabá mine.

The Cuiabá gold deposit is part of the Archean-Proterozoic ( $\mathrm{Au}, \mathrm{Fe}, \mathrm{Mn}$ ) metalogenetic district called the Iron Quadrilateral, located on the southern border of the Sao Francisco Craton. This world-class orogenic gold deposit is part of the Rio das Velhas Greenstone Belt, a typical association of maficultramafic volcanic rocks, banded iron formations (BIFs), carbonaceous phyllites and micaceous phyllites, metamorphosed into greenschist facies. The predominant sulfide mineralization is hosted in the Archean Cuiabá-BIF and related to the areas of hydrothermal alteration. Three other styles of mineralization have been identified in the deposit as potential orebodies but have not been economically characterized yet: Shear-related quartz veins, Fe-rich disseminated sulfide minerals in, and shearrelated quartz-carbonate veins.

The Cuiabá Gold deposit consists of meta-sedimentary and meta-volcanic rocks, with typical mineral paragenesis of metamorphic conditions associated with greenschist facies. As shown in Figure 1, the local lithostratigraphic horizons include a lower meta-mafic unit (MAN), discrete hydrothermal strata in the proximal zone (X2), intermediary zone (X2CL) and distal zone (MANX), BIF and metachert (carbonate, carbonaceous and ferruginous), carbonaceous phyllite $(\mathrm{XG})$, a metamafic superior unit (MBA) also divided into hydrothermal proximal zone (X2), intermediate zone (X2CL) and distal zone (MBAX) and at the top of the column, metavolcanoclastic rocks (XS) micaceous phyllites (X1), Rodrigues et al (2007).

According to Fernandes et al (2016), the final shape of the fold in which the orebody occurs (See Figure 1), is linked to three deformational phases; and each presents its associated main structures. The phases are: a) phase D1 with inclined and closed folds with rakes to east south- east and generation of the foliation S1. It has gold mineralization associated with deformed pyrrhotite; b) phase D2 with tight inclined coaxial folds to phase D1 with rakes to east sout-east and generation of the foliation S2. It has gold mineralization associated with subhedral pyrite in quartz-carbonate venules parallel to the axial planes of these folds; c) phase D3 with mild folds of subhorizontal axis and vergence to the west, whose axial planes define as a spaced crenulating cleavage in a north-south direction. This phase only segments locally the structures previously generated.

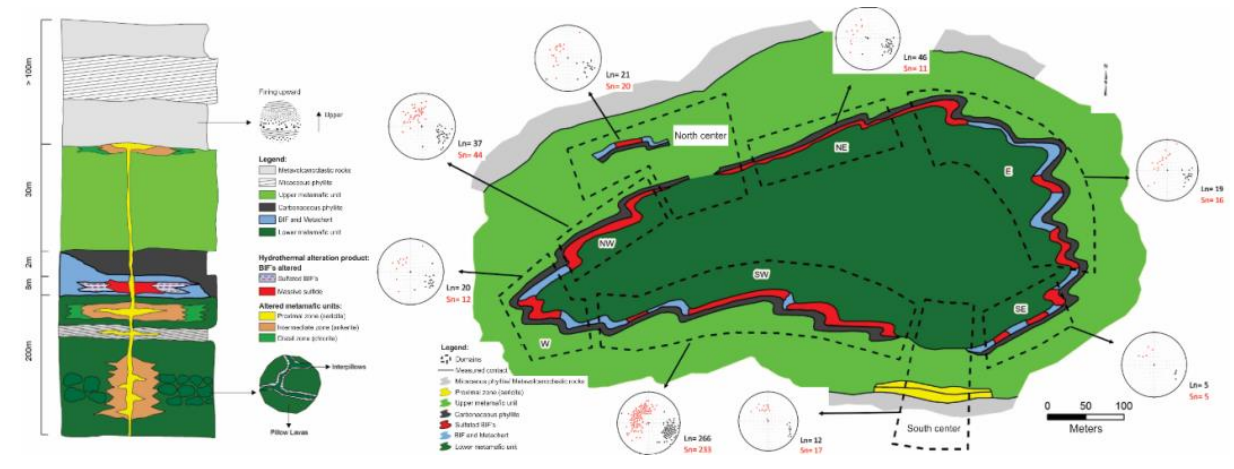

Figure 1. Lithostratigraphic column of the Cuiabá deposit, with associated alteration hydrothermal and Cuiabá deposit map with structural domains and defined stereograms: Ln - folding axis D1/D2; Sn - Polar point of foliation S1/S2 (modified by Fernandes et al( 2016) 


\section{OBSERVED MECHANISMS}

This study is specifically concerned with the Serrotinho decline, one of the Cuiabá main ramps and located in the deeper parts of the mine. The rock mass mapped at the Serrotinho decline is generally competent and strong, however, it is highly foliated and, therefore, prone to anisotropic stressfracturing, with buckling and rock mass bulking. Depending on the bulking magnitude, the shotcrete can debond from stable ground and tends to crack and spall.

In underground excavations situated in anisotropic hard rocks, large deformations are controlled by the presence of foliation and their respective orientation in relation to the opening direction, Karampinos et al (2015). Figure 2 a shows stress induced failures tend to occur in regions where the foliation is subparallel to the excavation walls. In these regions, there is a high concentration of shear stresses, leading to contraction along the foliation planes and dilation in the orthogonal direction, towards the opening. This dilation increases the deflection of the foliation planes, resulting in the buckling mechanism that also leads to rock mass bulking (See Figure $2 b$ ). In some sections of the ramp, one can also observe a complete shear failure of the rock mass causing a convergence of the excavation.
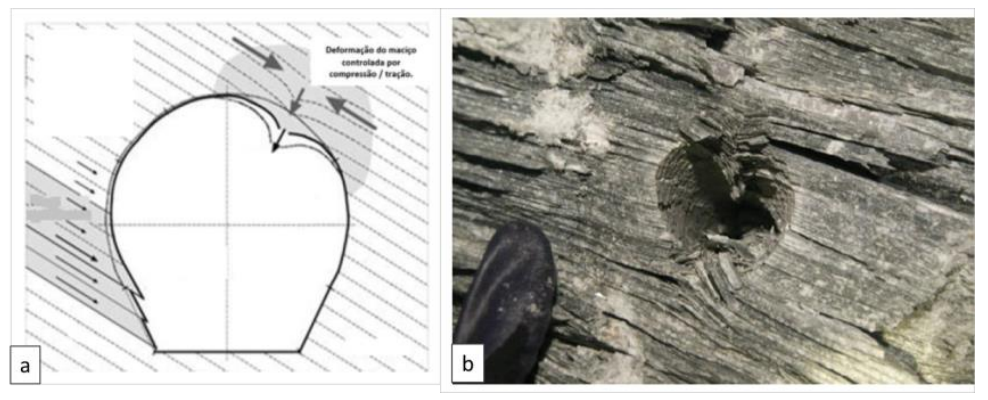

Figure 2. (a) Failure mechanism of excavations of foliated rock masses (b) Buckling mechanism in a borehole in a foliated rock at Cuiabá Mine (Pimenta, 2018)

\section{Support damage mapping}

The failure mechanisms presented above caused ground displacements in the order of $15 \mathrm{~cm}$, and this movement led to substantial damage to the support and reinforcement in the Cuiabá mine (See Figure 3). The support system initially installed at the Serrotinho ramp consisted of shotcrete and rockbolts spaced $1,5 \mathrm{~m} \times 1,5 \mathrm{~m}$ and $2 \mathrm{~m}$ from the floor.

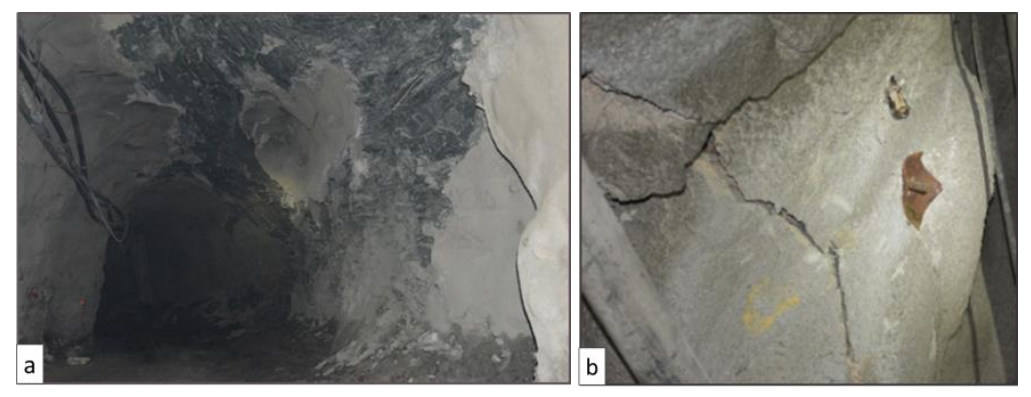

Figure 3. Damage in the support system observed underground in the Serrotinho ramp. (a) Failure of the shotcrete. (b) deformed plates. In some regions, the plates were completely sheared from the rock bolts

To improve the understanding of the reasons for damage occuring in the support and reinforcement over time, a methodology was established and damage mapping was carried out in the Serrotinho decline. This methodology was based on work described by Sandy et al (2010) - with some adjustments 
- to capture the specific conditions and the support system applied at the Cuiabá mine. The details of this developed methodology are presented in Padula et al (2019).

Table I describes the three main points of observation: 1) Percentage of the cross section of the gallery with a damaged shotcrete 2) Cracks aperture 3) Rock bolts exposure

Table I. Criteria to quantify the damage in the support system

\begin{tabular}{|c|c|c|c|c|c|c|c|c|}
\hline & & $\begin{array}{r}\text { SU } \\
\text { (SHO }\end{array}$ & $\begin{array}{l}\text { RT } \\
\text { (ETE) }\end{array}$ & & & & $\begin{array}{l}\text { NFORCEM } \\
\text { ROCKBOLT }\end{array}$ & \\
\hline 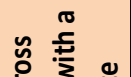 & $\%$ & Rating & & $\begin{array}{c}\text { Aperture } \\
(\mathrm{cm})\end{array}$ & Rating & & Exposure & Rating \\
\hline$\stackrel{0}{\square}$ & 0 & 40 & & 0 & 40 & & Without & 20 \\
\hline 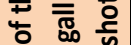 & $0-20$ & 30 & 气̆ & $<0,5$ & 30 & ఊ్ఠ & 8vitist & \\
\hline 品 § & $20-40$ & 20 & ปัँ & $0,5<\mathrm{e}<1$ & 20 & $\frac{\varepsilon}{\pi}$ & $<30 \mathrm{~cm}$ & 10 \\
\hline 䒕 & $40-60$ & 15 & & $1<e<2$ & 15 & & - socii & 10 \\
\hline 힘 & $60-80$ & 10 & & $2<e<4$ & 10 & & $>30+>$ & 0 \\
\hline & $80-100$ & 5 & & $>4$ & 5 & & & \\
\hline
\end{tabular}

By summing the rating obtained from each of these parameters, it is possible to obtain the level of damage to the support system as shown in the Table II. By applying the methodology described above, damage mapping was carried out as shown in Figure 4. It served as an important tool to calibrate the numerical modelling presented in the sections below.

\section{Table II. Support system damage classes}

\begin{tabular}{|c|}
\hline \multicolumn{2}{|c|}{ Damage Classes } \\
\hline Without damage \\
\hline 80-100 \\
\hline Low damage \\
\hline $60-80$ \\
\cline { 1 - 1 } Moderate damage \\
\hline 40-60 \\
\hline High damage \\
\hline $20-40$ \\
\hline Extremaly high damage \\
\hline $0-20$ \\
\hline No shotcrete \\
\hline
\end{tabular}

\section{MONITORING}

After undertaking a damage mapping in the decline, which already indicated the regions of excessive damage in the support system, it was necessary to execute a monitoring plan. The plan consisted of tape extensometer convergence measurements, as well as filming with borehole cameras through holes in the rock mass.

The convergence measurements were executed on a weekly basis and the mean velocity of the convergence sections (mm/week) is presented in Figure 5. The areas with a higher damage in the support system (See Figure 4) correlates with the area that presented a higher velocity in the convergence monitoring (See Figure 5). Figure 6 presents the results of the borehole camera monitoring. It is observed that the thickness of the failed material varied from $1,0 \mathrm{~m}$ to $0,5 \mathrm{~m}$. 


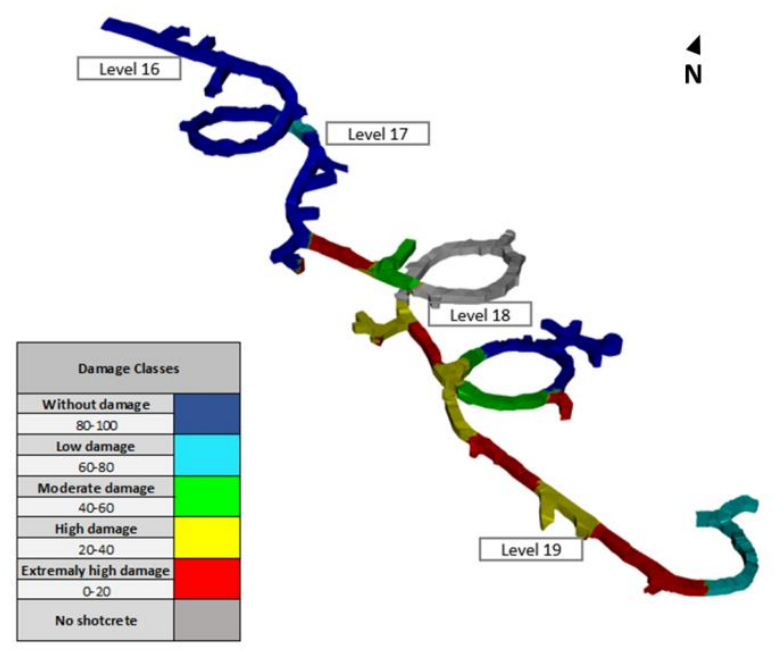

Figure 4. Damage mapping of the Serrotinho decline generated in GEM4D (Basrock)

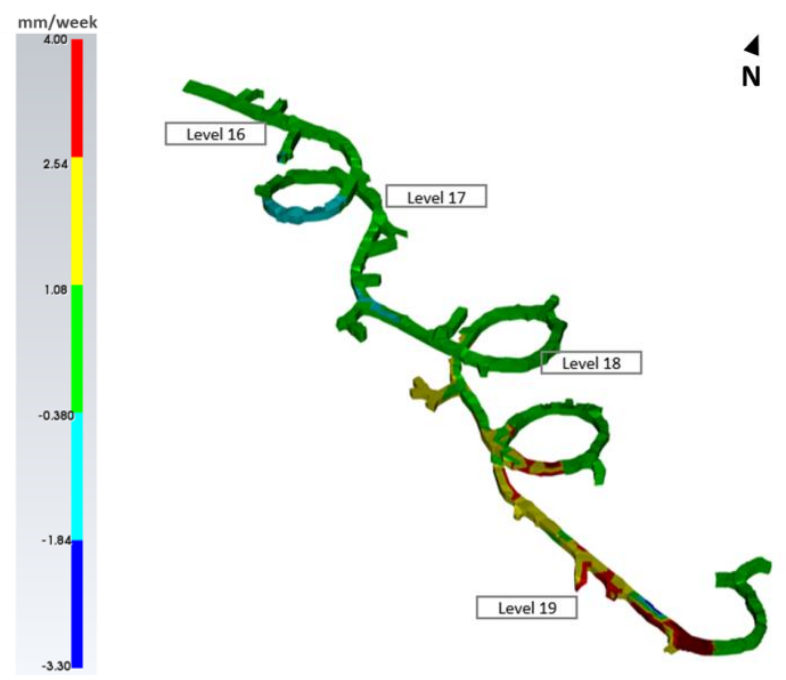

Figure 5. Velocity (mm/week) of the convergence sections of the Serrotinho ramp interpolated using GEM4D (Basrock)

\section{NUMERICAL MODELING}

An elastic model using the boundary element code MAP3D was used due to its ability to simulate large and complex excavations, allowing 3D stress-strain analyses in a relatively short run time. Any type of numerical model, despite its complexity, should generate reasonable results if they are properly compared with actual rock mass behavior. As mentioned by Barsanti and Basson (2015), calibration cannot be achieved with elastic modeling, however correlation can sometimes be achieved between damage and stress/strain results.

Shotcrete cracking was observed at Level 19 of the Serrotinho decline, even before stoping was carried out in proximity to it; however, the damage significantly increased after mining occurred. The aim of the numerical modelling was to analyze the stress changes induced by stoping on the decline. Stress measurement tests were conducted at Cuiabá in 2004, 2016 and 2017. The results of the stress 
measurements were used by Itasca Consulting to generate a 3D model to obtain an average in situ stress field that better fits these measurements. Details of the calibration process and results are described in Silva et al (2018). For depths below $1000 \mathrm{~m}$, the following relation was found between pre-mining principal stresses and vertical/horizontal stress relation $(\mathrm{K})$ :

$$
\begin{aligned}
& \sigma_{1}=\sigma_{v}=\rho g h \\
& \sigma_{2}=\sigma_{H}=0.5 \sigma_{1}+15 \\
& \sigma_{3}=\sigma_{h}=0.3 \sigma_{1}
\end{aligned}
$$

$$
K_{H}=0.5+200 / \text { depth }
$$
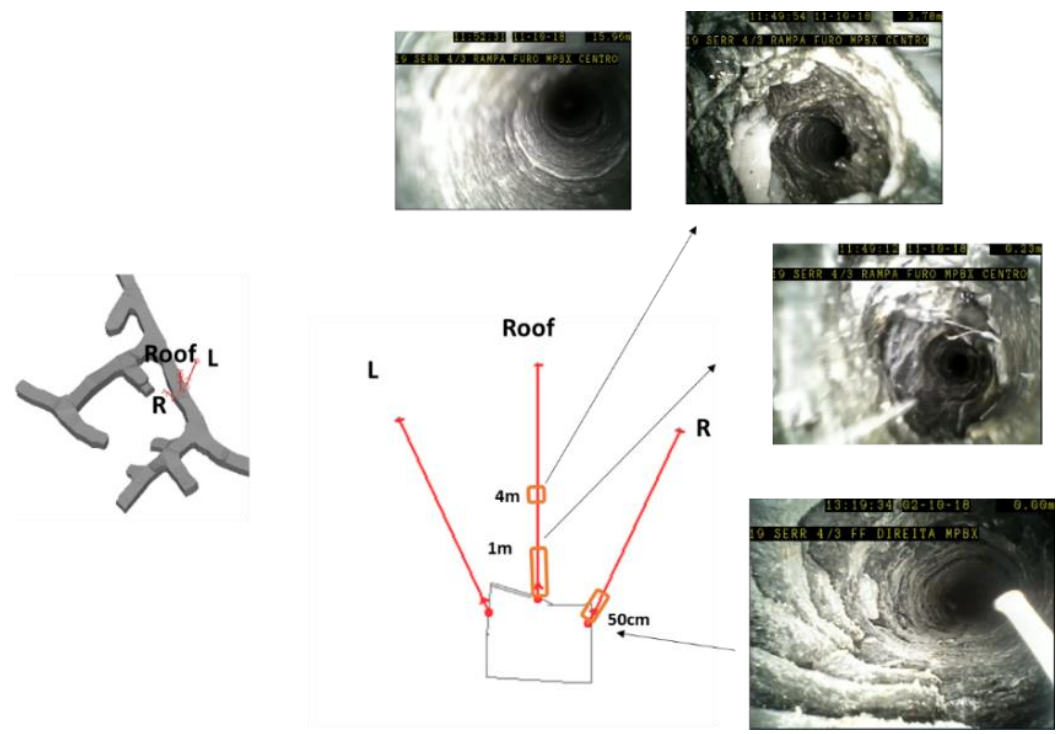

Figure 6. Failures zones obtained by the borehole camera monitoring [4]

See Table III for a summary of the material properties used in the model. The rock mass deformability and strength values were obtained from uniaxial and triaxial tests carried out on the main lithotypes, and geological strength index (GSI) is based on field mapping. In modelling, the rock mass was assumed to be continuous, isotropic, homogenous and linearly elastic. As an initial correlation process it was considered adequate; but future anisotropic, non-elastic and discontinuous models should be applied in order to better capture the observed mechanism.

Figure 7 (a) shows the 3D model, comprising the excavations around the decline. Grid lines for results calculation were placed at the top of the decline, and the model was staged in two steps: prior to and after the excavation of the stopes in the level 16, level 17 and level 18. As shown in 7 (b), the maximum induced displacement after the stoping was $1 \mathrm{~cm}$, considerably smaller than the real displacements observed in field and obtained by the convergence measurements (Up to $15 \mathrm{~cm}$ ). According to Kaiser (2010), continuum models are limited on correctly reproducing the unidirectional bulking process and tend to underestimate the displacements acting on the support due to the stress fracturing. 
Table III. Material properties input at the model

\begin{tabular}{|c|c|c|}
\cline { 2 - 3 } \multicolumn{1}{c|}{} & Host Material & Ore \\
\hline Lithotype & Schist & BIF \\
\hline Rockmass Young Modulus (GPa) & 25 & 50 \\
\hline Poisson ratio & 0.27 & 0.22 \\
\hline Uniaxial Compressive Strength (MPa) & 68 & 197 \\
\hline GSI & 70 & 73 \\
\hline m (Hoek Brown) & 4 & 7.6 \\
\hline s (Hoek Brown) & 0.032 & 0.050 \\
\hline
\end{tabular}

Although the magnitude of displacements might be underestimated by the model, it is possible to correlate the major displacement regions with those with the highest support damage (See Figure 4) and higher displacement rate in the convergence sections (See Figure 5). The results show that the sectors of the decline that are perpendicular to the major horizontal stress, more precisely around $120^{\circ}$ azimuth, tend to be subjected to the greatest displacements after the nearby stopes were mined. This correlation of the damage zones with the induced displacement in the excavations was useful to obtain a more accurate criterion to analyze the planned geometry of the ramp and to avoid similar issues in the future.

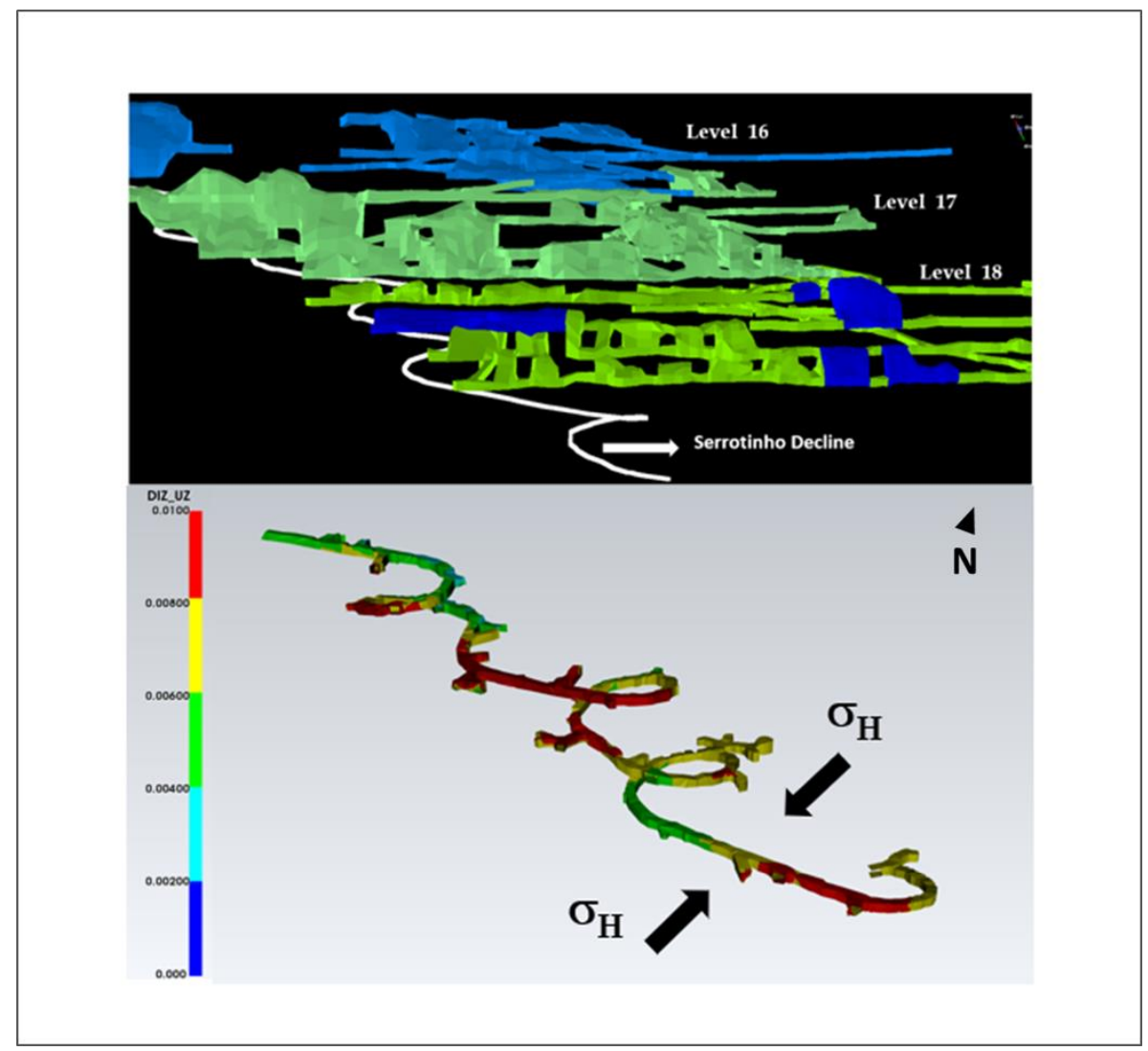

Figure 7. (a) MAP3D model with stoping areas around Serrotinho decline (b) Vertical displacement increase at the decline after mine of the stopes 


\section{SUPPORT ADJUSTMENT}

A ground support system consists of a surface support that is in contact with the excavation boundary and reinforcement embedded into the rock mass. Under static conditions, these elements can work relatively separately, as the requirement for them to work together is minimal. Practices such as shotcreting over reinforcement bolts, which does not provide significant interaction, exemplifies this condition, Charette and Bennet (2017).

However, in dynamic or quasi-static conditions the compatibility of these components with each other determines the effectiveness and capacity of the overall ground support scheme. Under these scenarios, the support scheme is as good as the weakest link and that is where the damage will initiate from Barrett and Player (2002). Therefore, it is critical to guarantee a good connection between both elements Charette and Bennet (2017). In case the surface support, or one of the connecting elements (plates and nuts), fails prematurely, the additional load capacity of the reinforcement element could be a waste of resources, Kaiser et al (996).

The connection, or the plate, is usually designed to be stronger than the reinforcement element as plate failure can generate the inoperability of the entire support scheme. A well-designed face plate can act as a system load indicator. The total deformation and energy capacity of the bolt can be increased from $3 \mathrm{~kJ}-5 \mathrm{~kJ}$ if the plate is designed to deform in the yielding zone of a rock bolt. The initial deformation of the plate should occur in the yielding zone of the bolt and ultimately fail after the reinforcement element fails, Charette and Bennet (2017).

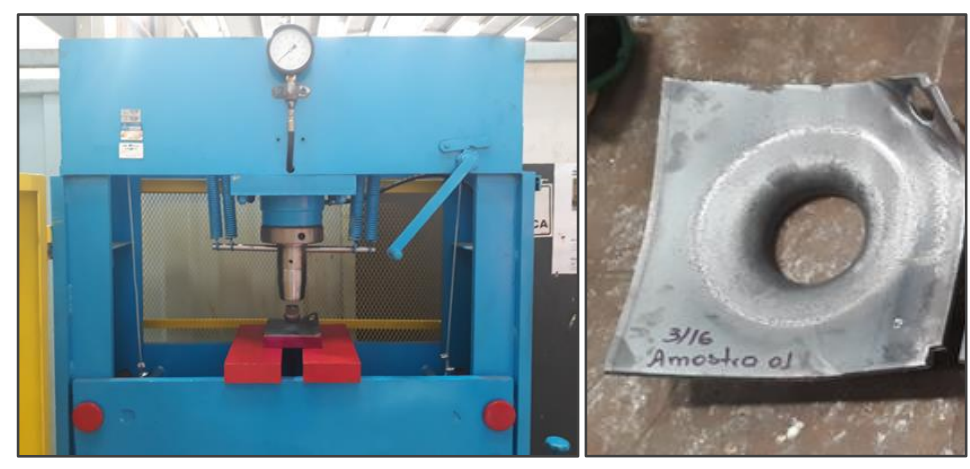

Figure 7. Laboratory tests carried out to obtain the capacity of the plate

As some plate failures were observed in the field, indicating that this element could be the reinforcement weakest link, laboratory tests were done at Cuiabá to obtain the capacity of the different types of plates (See Figure 7). The test consists of pressuring the nut through the plate with a hydraulic jam until the nut had completely penetrated the plate. Plates with a thickness of $4,8 \mathrm{~mm}$ and $8,0 \mathrm{~mm}$ started to deform at $6 \mathrm{t}$ and $12 \mathrm{t}$, and the nut penetrated the plate at $8 \mathrm{t}$ and $18 \mathrm{t}$, respectively.

In order to understand and illustrate the compatibility of each of the elements of the reinforcement system, two flowcharts were elaborated: one associated with the current support system (See Figure 8a) and the other related to the recommended assembly (See Figure $8 b$ ). The capacities presented in these flowcharts correspond to the rock bolt steel and plate capacities and are not related to the bond strength. This assumption is considered adequate because the portion of the rock bolt inside the stable ground (Around $2 \mathrm{~m}$ ) is sufficient to cause the rock bolt to fail. Based on these diagrams, one can see that the current reinforcement system would fail at $8 \mathrm{t}$ and would not allow the rock bolt to yield. However, the recommended reinforcement system provides a total capacity of $17 \mathrm{t}$ and the rock bolt will yield completely before the failure of the system. In addition to the thicker face plate, the proposed assembly would also have a more ductile rock bolt with an elongation of $33 \%$. 
The recommended spacing between the rockbolts was 1,2 $\mathrm{m} \times 1,2 \mathrm{~m}$. According to Potvin et al (2008), there are clear advantages in employing tight reinforcement patterns as they result in a stronger reinforced shell and more uniform surface deformations.

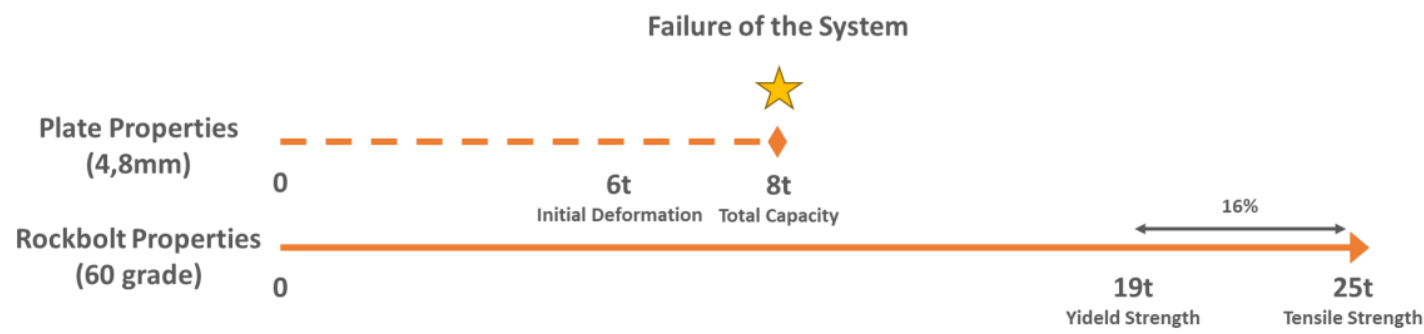

Figure 8a. Flowcharts to illustrate the load and displacement capacity of the current reinforcement system with a plate with 4,8 $\mathrm{mm}$ and a rockbolt with 60 grade steel

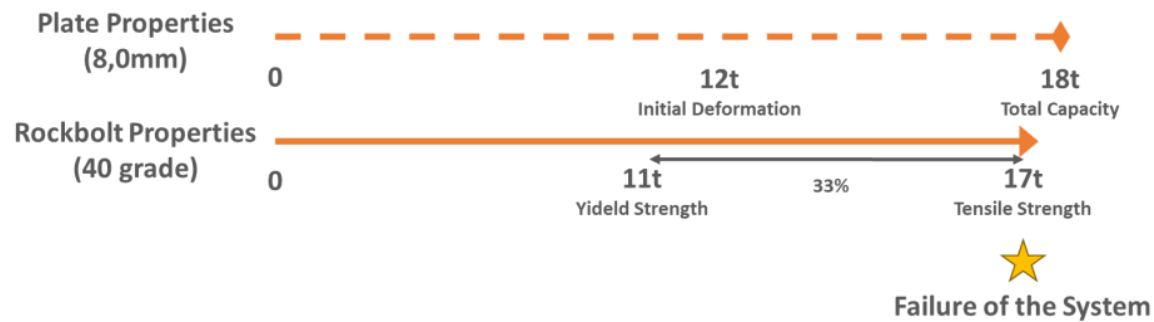

Figure 8b. Flowcharts to illustrate the load and displacement capacity of the recommended reinforcement system with a plate with 8,0 mm and a rockbolt with 40 grade steel

The maximum displacement observed in field was around $15 \mathrm{~cm}$, thus the surface support was designed based on this value. As can be seen in the Table IV Louchnikov et al (2014), the combination between fiber reinforced shotcrete (FRS) with $6 \mathrm{~cm}$ welded mesh (WM) pinned over it, is capable of absorbing $21 \mathrm{~cm}$ of displacement. Therefore, this surface support is considered adequate. It is important to remember that the tests presented below were executed under stiff boundary conditions. If they were executed under soft boundary conditions, the maximum displacement at failure of the FRS $60 \mathrm{~mm}+$ WM would be greater than $21 \mathrm{~cm}$. 
Table IV. Capacities of surface support systems based on static loading tests under stif' boundary conditions

\begin{tabular}{|l|c|c|c|}
\hline Type of surface support & $\begin{array}{c}\text { Energy } \\
\text { absorption } \\
\text { per unit area } \\
\left(\mathbf{k J}^{2} \mathbf{m}^{2}\right)\end{array}$ & $\begin{array}{c}\text { Peak load } \\
\text { at failure } \\
(\mathbf{k N})\end{array}$ & $\begin{array}{c}\text { Maximum } \\
\text { displacement } \\
\text { at failure } \\
\text { (mm) }\end{array}$ \\
\hline FRS $60 \mathrm{~mm}$, synthetic fibre & 0.75 & 25 & 60 \\
\hline FRS $80 \mathrm{~mm}$, synthetic fibre & 2 & 65 & 80 \\
\hline FRS $110 \mathrm{~mm}$ with embedded WM & 6 & 120 & 120 \\
\hline WM $100 \times 100 \times 5.6 \mathrm{~mm}$ & 1.3 & 45 & 210 \\
\hline FRS $60 \mathrm{~mm}+$ WM over & 2 & 45 & 210 \\
\hline FRS $80 \mathrm{~mm}+$ WM over & 3.3 & 65 & 210 \\
\hline MINAX M85/2.7 & 1.7 & 55 & $185^{\mathrm{a}}$ \\
\hline TECCO G80/4 & 6 & 110 & $250^{\mathrm{a}}$ \\
\hline FRS $60 \mathrm{~mm}+$ MINAX M85/2.7 & 2 & 55 & 185 \\
\hline FRS $60 \mathrm{~mm}+$ TECCO G80/4 & 6.8 & 110 & 250 \\
\hline FRS $80 \mathrm{~mm}+$ MINAX M85/2.7 & 4 & 65 & 185 \\
\hline FRS $80 \mathrm{~mm}+$ TECCO G80/4 & 8 & 110 & 250 \\
\hline FRS $110 \mathrm{~mm}+$ TECCO G80/4 & 12 & 120 & 250 \\
\hline HEA mesh & 2.5 & 160 & $800^{\mathrm{b}}$ \\
\hline Strap mesh & 1.5 & 50 & 210 \\
\hline
\end{tabular}

\section{CONCLUSION}

As the mine deepens, new challenges need to be solved and a deformable ground conditions will be experienced. This new situation requires adjustments in the excavation designs and in the support system.

The analysis presented assisted in the understanding of the problem as well as in the definition of actions to reduce the occurrence of production stoppages and required rehabilitations of development. The damage mapping was important to obtain a three-dimensional view of the damage in the support and reinforcement. Together with the monitoring, it was a useful tool to execute initial correlations with the numerical modeling. By having a correlated criterion in the numerical model, it was possible to critically appraise proposed new mine planning designs. These will also require more refinement and calibration over time. Anisotropic, non-linear and discontinuous models should also be applied in the future aiming to better capture the observed mechanism.

Understanding the interactions between the various support and reinforcement elements was a critical step in formulating a new design capable of guaranteeing the operability of the underground excavations. This new design has a higher support capacity and can cope with larger displacements. The performance of the adjusted system is illustrated in Figure 10.

According to Potvin and Hadjigeorgiou (2008), there is no unique solution to control large scale deformations in rock. Therefore, a multidisciplinary effort is required to establish the actions to be taken to guarantee the accessibility of the permanent excavations. 

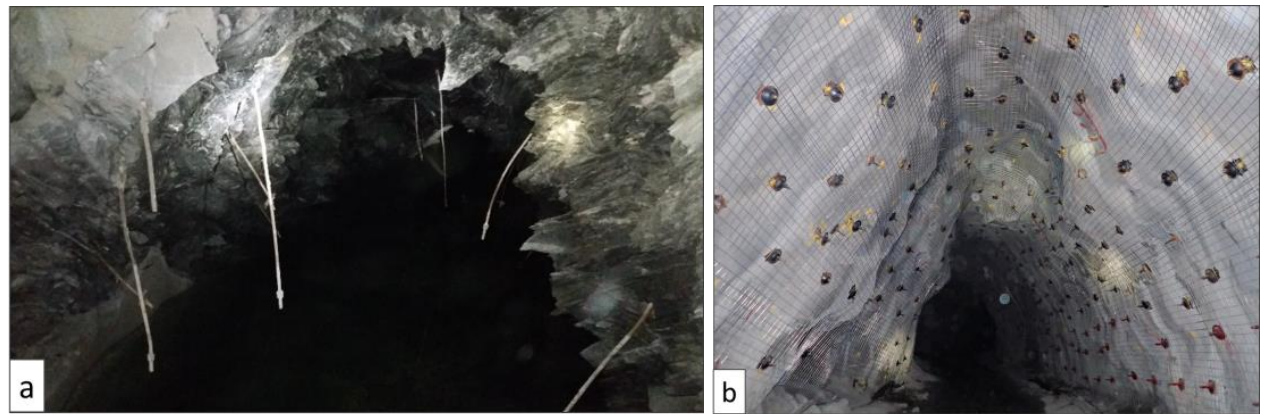

Figure 10. Adjusted support system applied in the Serrotinho ramp. (a) Damaged support system previously the rehabilitation. (b) Rehabilitated gallery with the new support system

\section{REFERENCES}

Aydan, Ö., Akagi, T., \& Kawamoto, T. (1996). The squeezing potential of rock around tunnels: theory and prediction with examples taken from Japan. Rock Mech. Rock Eng., 125-143.

Barla, G., Bonini, M., \& Debernardi, D. (2007). Modelling of tunnels in squeezing rock. Proc. 3rd Iranian Rock Mech. Conf., Tehran, Iran - Iranian Society for Rock Mechanics, 1267-1285.

Barrett, D., \& Player, J. (2002). Big bell, high stress at shallow depth. International Seminar on Deep and High Stress Mining, Australian Centre of Geomechanics, Perth.

Barsanti, B., \& Basson, F. (2015). Defining the role of elastic modelling in underground mine design. Underground Design Methods, Australian Centre for Geomechanics, Perth, 107-120.

Charette, F., \& Bennett, A. (2017). The importance of the face plate as part of an engineered holistic ground support scheme in dynamic conditions. Deep Mining 2017: Eighth International Conference on Deep and High Stress Mining, 709-722.

Fernandes, R., Endo, I., Pereira, R., Rivarola, I., \& Souza, J. (2016). Geologia e Evolução Estrutural do Depósito Aurífero Cuiabá: Novas Perspectivas para a Exploração Mineral,. Seção Pôster. In: VII Simpósio Brasileiro de Exploração Mineral, SIMEXMIN, Ouro Preto, ADIMB.

Silva, R., Lorig, L., Toro, D., Pimenta, L., \& Costa, L. (2018). Stress Calibration at Cuiabá Mine, Brazil. SASORE - $3^{\circ}$ Simposio Sudamericano de Excavaciones en Roca.

Kaiser, P. (2010). Deformation based support selection for tunnels in strainburst-prone ground. Australian Centre for Geomechanics.

Kaiser, P., McCreath, D., \& Tannant, D. (1996). Canadian Rock Burst Support Handbook. Canadian Rockburst Research Program 1990-1995, Canadian Mining Industry Research Organization, Sudbury.

Karampinos, E., Hadjigeorgiou, J., Hazzard., J., \& Turcotte, P. (2015). Discrete element modelling of the buckling phenomenon in deep hard rock mines. International Journal of Rock Mechanics and Mining Science, 346-356.

Louchnikov, V., Sandy, M., Watson, O., Orunesu, M., \& Eremenko, V. (2014). An Overview of Surface Rock Support for Deformable Ground Conditions. 12th AUSIMM Underground Operators Conference / Adelaide, SA, 24-26 March, 57-65. 
Mercier-Langevin, F., \& Hadjigeorgiou, J. (2011). Towards a better understanding of squeezing potential in hard rock mines. Australian Centre for Geomechanics, The University of Western Australia, 36-44.

Padula, R. C., Costa, L. C., \& Amaral, J. P. (2019). Method to execute damage mapping in the support and reinforcement of underground mines. Case study: Cuiabá mine - Sabará, MG/Brazil. International Congress on Rock Mechanics and Rock Engineering (in pres).

Pimenta, L. M. (2018). Análise das zonas plastificadas da rampa Fonte Grande Sul (Mina CuiabáSabará/MG) via modelagem numérica. XIX Congresso Brasileiro de Mecânica dos Solos e Engenharia Geotécnica. Salvador.

Potvin, Y., \& Hadjigeorgiou, J. (2008). Ground support strategies to control large deformations in mining excavations. SAIM M. Sanire and ISRM - 6th International Symposium on Ground Support in Mining and Civil Engineering Construction, 545-560.

Rodrigues, L., de Oliveira, C., \& Friedrich, G. (2007). The Archean BIF-hosted Cuiabá Gold deposit, Quadrilátero Ferrífero, Minas Gerais, Brazil. Ore Geology Reviews, v.32, 543-570.

Sandy, M., Sharrock, G., Albrecht, J., \& Vakili, A. (2010). Managing the Transition from Low Stress to High Stress Conditions. Second Australasian Ground Control in Mining Conference.

Steiner, W. (1996). Tunneling in squeezing rocks: case histories. Rock Mech. Rock Eng., 211-246.

Varden, R., \& Woods, M. (2015). Design approach for squeezing ground. Underground Design Methods, 2015. Perth, Australia., 489-504.

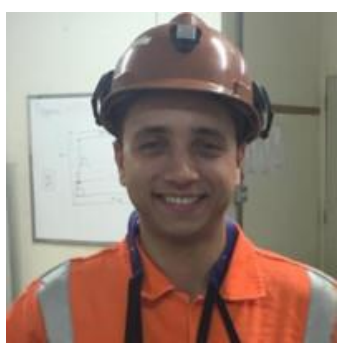

\section{Leandro Caio Barbosa Costa}

Chief of Rock Mechanics CBLM Mines

AngloGold Ashanti

Geotechnical Engineer with 7 years of experience in underground mines with Master's degree in Geotechnics Applied to Mining. The master thesis was about the dilution control in narrow vein mines. Currently is responsible for the rock mechanics area in the Cuiabá and Lamego mines in Sabará, Brazil (AngloGold Ashanti). Cuiabá is one of the deepest mines in Brazil. 